\title{
SUMMARY AND INTERPRETIVE GEOCHEMICAL MAP OF WEST VIRGINIA
}

\author{
By
}

\author{
K.C.Watts, Jr., M.E. Hinkle, and W.R. Griffitts
}

\section{INTRODUCTION}

The geochemical maps in this series were prepared to assist the evaluation of mineral resources in West Virginia. Other relevant geochemical maps in this series include I-2364-D, I-2364-E, I-2364-F, and I-2364-G.

These maps and figures were compiled from geochemical data generated by the National Uranium Resource Evaluation (NURE) program of the U.S. Department of Energy (DOE), and from supplemental analyses of NURE samples conducted by the U.S. Geological Survey (USGS). The NURE samples are archived by the USGS and the data are released in a USGS Open-File Report (Adrian and others, 1992). The USGS was not able to conduct new field work to further evaluate the results. Consequently, the interpretations are tentative.

Map A (1:1,000,000 scale) includes the outline of the state, lanthanum isopleths, simplified geology, and structural features (Woodward, 1968). Lanthanum anomaly patterns correlate closely with major regional faults, and in particular with fault intersections, which suggests faultcontrolled mineralization in those areas. Although lanthanum is shown on map A, anomalies of other key elements, such as titanium, cerium, thorium, and iron, show similar regional relationships with these major faults.

Map B (1:1,000,000 scale) includes the outline of the state, anomaly tracts, simplified geology, and structural features (Woodward, 1968). Five tracts contain regional stream-sediment anomalies within extensive geographic areas (tracts A, B, C, $\mathrm{L}-1$, and $\mathrm{L}-2$ ).

The figures (1:500,000 scale) show element concentrations within tracts A and B, summaries of element statistics, and interelement comparisons for the entire state and the various anomaly tracts.

\section{METHODS}

During the NURE sampling program, the DOE collected 2,873 stream-sediment, 2,819 stream-water, 3,070 well-water, and 853 spring-water samples from the parts of the Bluefield, Charlottesville, Cumberland, and Pittsburgh $1^{\circ} \times 2^{\circ}$ quadrangles that are in West Virginia. The methods of sample collection used are described by Price and Jones (1979). All of the NURE samples were analyzed by neutron activation at the Savannah River Laboratory (SRL) of the DOE for $\mathrm{Hf}, \mathrm{Al}, \mathrm{Ce}, \mathrm{Dy}, \mathrm{Eu}, \mathrm{Fe}, \mathrm{La}, \mathrm{Lu}$, $\mathrm{Mn}, \mathrm{Sc}, \mathrm{Sm}, \mathrm{Na}, \mathrm{Ti}, \mathrm{V}$, and Yb (Cook, 1981a,b; Fay, 1981; Cook and others, 1982; Fay and Cook, 1982). All of the SRL analytical data were retrieved from computer tapes archived by the USGS.

A subset of 354 NURE stream-sediment samples containing high elemental concentrations was selected from an area (approximately $1^{\circ} \times 1^{\circ}$ ) centered on Barbour and Harrison Counties (tract A, map B). These samples were analyzed for 35 elements using direct-current arc emission spectrography (ES) (Grimes and Marranzino, 1968; Motooka and Grimes, 1976) and for Au using an atomicabsorption (AA) procedure (modification of Thompson and others, 1968; see Adrian and others, 1992). A second subset of 185 stream-sediment samples collected in Grant, Hardy, and Pendleton Counties (tract B) was also analyzed for 35 elements using ES and further analyzed for As, Bi, $\mathrm{Cd}, \mathrm{Sb}$, and $\mathrm{Zn}$ using induction coupled plasma-atomic emission spectrography (ICP-AES) (Motooka, 1988). Data obtained from these supplemental analyses and NURE analyses used for the geochemical maps in this map series are tabulated in Adrian and others (1992).

All geochemical data were stored in the USGS Rock Analysis Storage System (RASS). Statistical analyses of the data were conducted with computer programs developed by the USGS (VanTrump and Miesch, 1977). For the purpose of data evaluation and interpretation, means, standard deviations, correlation coefficients, histograms, and percentiles were calculated for the data sets. Table 1 summarizes some of these statistical parameters for the statewide NURE data set.

Significant product-moment correlation coefficients provide clues to sample mineralogy and possible mineraldeposit types within the drainage basins, both major considerations in the geochemical interpretations. For the reader not familiar with correlation analysis and how it is 
used, a perfect correlation between two chemical elements is a positive 1.000 , a perfect antipathy between elements is a negative 1.000 , and a random or no relationship is 0.000 . The relative association (or lack of association if negative) between element pairs ranges between 0.000 and 1.000 , depending on the amount that two elements are geochemically associated.

The data were further examined by $\mathrm{R}$-mode factor analysis. The R-mode factor analyses were conducted on total data sets and subsets after removal of qualified values using the USGS program REPLAC, which creates real values by multiplying qualified values by percentages of the lower determination limits. The purpose of R-mode factor analysis is to determine suites of elements that can be grouped together on the basis of underlying geologic or geochemical associations. This method reduces a large number of chemical variables to fewer, more readily explainable relationships. Details of the statistical theory can be found in such standard textbooks as Harman (1960) and Davis (1973).

Key elements were selected for plotting on the basis of the statistical data and the relevance each element may have to mineral-deposit-forming processes. Data were then plotted on the maps as site-specific symbols and isopleths. Both types of plots use classes of data that are the 50th, 75th, 85th, 90th, 95th, and 99th percentiles of the statistical distribution where the range of data allowed. These statistical parameters were used as a general guide to class selection, but there was no strict adherence where the data range did not allow such values to be used. The contour intervals on maps A and B represent the percentile intervals of the state-wide data base; the class intervals on the 1:500,000-scale maps (figs. 9, 12-17) are based on recalculations that were in turn based on the data subsets obtained from samples collected in individual tracts. The USGS contour program called CONPLOT (J.B. Fife, unpub. data-processing program, 1985) was used to generate the maps. The method uses a standard cell-average technique based on gridded data. For these maps cells are $5 \mathrm{mi}(1: 1,000,000$ scale $)$ and $2.5 \mathrm{mi}(1: 500,000$ scale $)$ on a side. A standard USGS plotting program (Van Trump and Miesch, 1977) was used to generate the symbol maps.

The tract boundaries (map B) were delineated on the basis of combined element distributions viewed from stacked transparent overlays of the computer-generated isopleth maps. The area enclosed by the tract boundaries is the maximum areal extent of the combined anomalies. Tracts A, C, L-1, and L-2 were mostly, though not entirely, delineated on the basis of combined titanium, cerium, and lanthanum distribution patterns, usually accompanied by anomalies of at least one of the following elements: thorium, manganese, aluminum, and iron. Supplemental analyses of stream-sediment samples collected from tract $\mathrm{A}$ indicate that they contain anomalous concentrations of $\mathrm{Cu}, \mathrm{Pb}, \mathrm{Zn}, \mathrm{Ba}, \mathrm{Sr}, \mathrm{Sn}$, and $\mathrm{Au}$, but despite the presence of chalcophile element anomalies, tract $\mathrm{A}$ is categorized as REE-lithophile in character. Tract B was delineated on the basis of combined chalcophile element anomalies in conjunction with $\mathrm{Ba}, \mathrm{Fe}, \mathrm{V}$, and $\mathrm{Mn}$ distribution patterns and is categorized as chalcophile in character. Tracts $\mathrm{C}, \mathrm{L}-1$, and $\mathrm{L}-2$ are categorized as REE-lithophile in character on the basis of current information; these tracts were not initially recognized and therefore samples were not reanalyzed for chalcophile elements by USGS methods.

We wish to clarify our use of the term "anomaly" in the discussions of this summary and interpretive geochemical map. We prefer to invoke the English usage of the term, which implies that something is unexpected in the given context, in this case geologic and geochemical context, and prefer not to equate the term "anomaly" with a direct indication of mineralization. There are a variety of potential causes for elevated element concentrations in stream sediments, and investigation of a geochemical anomaly should seek to identify those causes. Because mechanisms of mineral-deposit formation are concentration processes identical to those that form geochemical anomalies, any reported element concentration in geologic materials should be evaluated in the mineralogic and geologic contexts, as well as the geochemical and statistical contexts.

\section{GEOLOGY}

The most conspicuous geological feature of West Virginia is the contrast between the folded Appalachian Mountains in the eastern part of the state and the rather undeformed Appalachian Plateaus in the central and western parts of the state. The contrast between regions is also shown by stream-sediment geochemistry. Erosion of the folded Appalachian structures has produced parallel ridges and valleys with a rectilinear pattern trending northeast. Major streams follow one or more easily eroded formations and receive sediment from tributaries that drain the more resistant, hill-forming rocks. Inasmuch as the geochemical samples were collected mostly from the tributaries, the resistant rocks provided a disproportionately large part of the sampled material. Correlation of geochemistry and specific formations is difficult because of the drainage pattern and the distribution of sample sites, although it is possible to make some reasonable inferences about the geochemical nature of the country rocks.

In contrast, the streams draining the Appalachian Plateaus Province, although influenced by the structural and erosional differences of the country rocks, tend to form dendritic patterns. Hence, the stream sediments better represent the most common local rock units, making 
correlation of the specific formations with the geochemistry much easier.

Rocks ranging in age from Cambrian to Permian are exposed in the folded rocks of the western part of the state, and Proterozoic rocks were found in deep drill holes. Rocks of Pennsylvanian age are the most widespread, lying at the surface of most of the Appalachian plateaus. They are covered by Permian rocks in the northwestern part of the state and have been stripped away near the eastern edge of the plateau to expose older rocks of Mississippian age.

Rocks older than Mississippian age are exposed only in the folded Appalachian Mountains in the eastern part of the state. Cambrian and Ordovician rocks predominate in the easternmost part of the panhandle. Most of the rocks of Mississippian and older age were deposited in or near marine environments. Pennsylvanian and Permian age rocks were mostly deposited in nonmarine environments. Distinctive lateral changes in lithology characterize both the Pennsylvanian age and older formations.

The lower part of the Cambrian section in the eastern part of the state consists mainly of gray, white, or greenish-gray sandstone, quartzite, and minor shale. These units do not appear to contain anomalously high elemental concentrations. The upper part of the Cambrian section is of more interest because it is more calcareous. The Tomstown Dolomite, at the base of the Cambrian section, is notable because it contains most of the manganese ore of Virginia and West Virginia as a residuum from early Tertiary weathering of this formation.

Carbonate rocks are also prominent in much of the Ordovician section. The Martinsburg Formation at the top of the section is predominantly gray shale and is overlain by the uppermost Ordovician unit, the Juniata Formation of red sandstone and shale.

The Silurian System contains predominantly clastic sedimentary rocks. Limestone, where present, is commonly clay rich. Localized units of pink to red sandstone and shale are present throughout the system. The Clinton Formation is composed of hematitic sandstone and iron formation that could contribute abnormal amounts of base metals to some geochemical samples.

The Upper Silurian formations change markedly from east to west. In the northwestern part of West Virginia, the total thickness of Silurian rock salt exceeds $50 \mathrm{ft}$ at depths of 6,000-9,000 ft (King and Kirstein, 1987). It is interlayered with sandstone, shale, and anhydrite. Although these evaporite deposits are not exposed at the surface, brines may ascend from them through fractures or other permeable zones in the host rocks. A highly corrosive brine is capable of mobilizing metals resident in the deeper host rocks, and under favorable circumstances could have transported them to near-surface sites of deposition.

The Devonian System contains shale and sandstone, with only minor limestone. Black shale is common in the lower part, which also contains glauconitic or pyritic shales; all of these may be hosts of unusual amounts of metals. Higher in the section are the rocks of the Chemung Group, which have been reported to contain traces of galena in several places.

Limestone, red and gray shale, and minor sandstone of the Greenbriar Formation are near the base of the Mississippian section, whereas at the top are the red, green, and gray shale and sandstone of the Mauch Chunk Group, which contains small deposits of carnotite in southern Pennsylvania (Dyson, 1955).

The rocks of the Pennsylvanian System are widely exposed at the surface, have been mined extensively for coal, and have been drilled extensively for coal and oil.

The Lower and Middle Pennsylvanian rocks mainly consist of sandstone where they crop out in the east-central part of the state. Clayey sediments and coal are more prominent in the subsurface. From east to west on the surface, shale and coal are common in the younger Pennsylvanian formations. During the 19th century, discontinuous beds and lenses of siderite, sparsely distributed throughout the section, provided small amounts of iron ore for industrial furnaces. The manganese content of these ores was apparently low.

The Lower Pennsylvanian Pocahontas basin in the southern part of the state is the older of two sedimentary basins in West Virginia. The source area of the clastic material that filled this basin was located to the southeast in what is now Virginia (Davis and Erlich, 1974). The source of the basinal detritus was a granodiorite batholithic complex that was completely eroded during the process of filling of the basin. The environment of deposition was a deltaic complex located next to an extensive sea (Englund and others, 1986). The sediments in the Pocahontas basin consist of alternating units of sandstone, shale, limestone, and coal of the Kanawha, New River, and Pocahontas Formations. Coal of the Pocahontas basin generally has lower sulfur content than that of the northwestern basin (Arkle, 1974). The Pocahontas basin can be seen as the "low sulfur coal field" in figure 11 of Barlow (1974).

The Dunkard basin, located in the northwestern part of the state, is Upper Pennsylvanian and Lower Permian. It overlaps the Pocahontas basin in approximately the middle of the state, in the area of Calhoun, Gilmer, Kanawha, and Roane Counties. The source area for the Dunkard sediments was located generally east-southeast of the basin, in eastern West Virginia and Virginia. The environment of deposition was also deltaic; however, the delta was much smaller than in the Early Pennsylvanian (Arkle, 1974; Donaldson, 1974). Sediments in the Dunkard basin consist of sandstone and shale of the Conemaugh Formation, and Monongahela and Dunkard Groups, which are primarily nonmarine, with minor interbedded marine sedimentary units and coal. 
Mafic igneous rocks of probable Triassic age have been found in Pendleton County, West Virginia and neighboring Highland County, Virginia (Darton and Diller, 1890). The intrusion of felsic alkalic rocks during the Jurassic and the intrusion of more mafic rocks once again during the Eocene (Garnar, 1956; Dennison and Johnson, 1971; Rader and others, 1986) indicate the continuation of intermittent igneous activity in eastern West Virginia and adjacent Virginia over a long time span. Mica peridotite dikes intrude the coal-measure sequence (Honess and Graeber, 1926; Pimentel and others, 1975) at two localities in Pennsylvania, indicating late igneous activity to the north. At one of these localities, the mica peridotite is Middle Jurassic, dated at $185 \mathrm{Ma}$ (Pimentel and others, 1975).

Thermal waters on the eastern margin of the state, possibly associated with the alkalic igneous activity, may provide a clue to the origin of geochemical anomalies throughout the state. In the western part of the state, several structural trends can be projected into the anomalous areas from Pendleton County. Thermal waters are probably a late-stage phenomenon related to waning alkalic igneous activity in Pendleton County and neighboring Virginia. Part of this waning igneous-geothermal activity seems to be related to the development of doming and geomorphic evolution of the Schooley peneplain; this activity may also have deposited some of the metals found in anomalously high concentrations in the region.

Rocks in the eastern part of West Virginia are tightly folded and thrust faulted in the typical fashion of the Valley and Ridge Province. The rocks that extend from the central part of the map area westward are deformed into northeast-trending open folds with frequent disruptions in strike, which are interpreted as crosscutting faults, geofractures, and joints that extend across the state from the Virginia border to the Ohio border (Woodward, 1968). A zone of inferred transcurrent faults in the basement is considered to be an eastward extension of the 38th-degree lineament of the midcontinent region (Woodward, 1968; Snyder and Gerdemann, 1965; Zartman, 1977; and fig. 1), but it is also related to the New York-Alabama lineament recognized by King and Zietz (1978). The coextensive distribution of regional structural features and regional anomalies of $\mathrm{Ti}, \mathrm{Al}, \mathrm{Ce}, \mathrm{La}, \mathrm{Th}, \mathrm{Fe}$, and $\mathrm{Mn}$ suggests that hypogene leakage and secondary dispersion along faults and fractures might be a significant cause of the geochemical anomalies of drainage basins within the coal-measure sequence of the western part of the state.

\section{GEOCHEMICAL PROCESSES}

Several elements of industrial (or economic) interest are concentrated in the stream sediments of West Virginia as the result of one or more of the following processes: (1) reaction of seawater with organic matter in the basins during the Paleozoic era (for example, $\mathrm{Zn}, \mathrm{V}$, and Mo); (2) direct precipitation and detrital concentration in the basins during the Paleozoic era (for example, Fe, Mn, V and REE); (3) hydrothermal mineralization during the Paleozoic era (for example, $\mathrm{Fe}, \mathrm{Mn}, \mathrm{Cu}, \mathrm{Pb}, \mathrm{Zn}, \mathrm{Ba}, \mathrm{Mo}, \mathrm{Co}$, and As); (4) post-Pennsylvanian tectonism and alkalic igneous and(or) geothermal activity (for example, Ti, $\mathrm{REE}, \mathrm{Cu}, \mathrm{Sr}, \mathrm{Ba}, \mathrm{Sn}$, and $\mathrm{Nb}$ ); (5) residual concentration by bedrock weathering from Tertiary to present (for example, $\mathrm{Mn}$ and $\mathrm{Fe}$ ); (6) artificial contamination past and present (for example, $\mathrm{Pb}, \mathrm{Mn}, \mathrm{Fe}$, and $\mathrm{Al}$ ); and (7) coprecipitation, sorption, and mechanical concentration of metalliferous minerals in the streambed past and present (for example, $\mathrm{Fe}, \mathrm{Mn}, \mathrm{Al}, \mathrm{Co}, \mathrm{As}, \mathrm{Ni}, \mathrm{Ba}$, and $\mathrm{Zn}$ ). More than one of these processes may have operated in sequence. Thus, as an example, metals precipitated or deposited with organic matter during the Paleozoic era may have been moved to other sites during subsequent hydrothermal mineralization or alkalic igneous activity. All of the above-mentioned processes are considered in the interpretations discussed below.

\section{REGIONAL GEOCHEMICAL PATTERNS}

Regional isopleth patterns that parallel the regional strike of the lithostratigraphic sequence (Hinkle, and others, 1994a,c; Watts and others, 1994) of $\mathrm{Mn}, \mathrm{Fe}$, and V (Hinkle and others, 1993c), and to some extent REE, show that the lithologic compositions of the country rock are reflected in those element concentrations that are only slightly above the regional (statewide) mean (table 1 and fig. 2). Sedimentary units that probably yield these slightly higher values in the stream sediments include both marine and nonmarine Devonian units, Pennsylvanian Allegheny, Kanawa, and Conemaugh Formations and Monongahela Group, and Upper Pennsylvanian and Lower Permian Dunkard Group. The regional isopleth maps of $\mathrm{Fe}, \mathrm{Mn}$, and $V$ show that concentrations of most elements increase upsection to the northwest with striking geochemical contrasts at the contact between Upper Pennsylvanian Monongahela Group rocks and the Lower and Middle Pennsylvanian rocks. Hence, the geochemical data appear to delineate the boundary of the Dunkard basin.

The plot (fig. 3) of the variation of elements (selected from NURE surveys) within the stratigraphic section includes the maximum concentrations in lower Paleozoic basal units upward, through units of the Upper Pennsylvanian and Lower Permian Dunkard Group. This plot shows that the lowest concentrations of most elements are within the lower Paleozoic units and Mississippian carbonate rocks. The low concentrations in the 
Mississippian section are probably due to the purity of the Greenbrier Limestone. The increase in all element concentrations is very noticeable in the Lower to Middle Pennsylvanian age rocks, but the concentrations of most elements decrease slightly in Upper Pennsylvanian and Permian strata. Concentrations of $\mathrm{Ti}, \mathrm{Fe}, \mathrm{Mn}$, and $\mathrm{V}$ continually increase upward in the section, which is consistent with the regional isopleth plots (Hinkle and others, 1994). Iron concentrations (fig. 3) increase substantially in the Middle to Upper Pennsylvanian units. The increase of titanium concentrations in Mississippian to Lower and Middle Pennsylvanian units is spectacular; in the upper part of the section, the concentration of titanium remains at a relatively steady level, declining only slightly in the Upper Pennsylvanian units. We have no explanation for the increase of titanium concentrations in the Lower and Middle Pennsylvanian units; however, the regional geochemical data indicate that there might have been an influx of titanium as a consequence of late alkalic igneous activity subsequent to basin sedimentation.

The distribution patterns of $\mathrm{Ti}, \mathrm{REE}, \mathrm{Th}, \mathrm{Al}, \mathrm{Fe}$, and $\mathrm{Mn}$ are regionally discordant at the highest levels of reported concentrations. It is unlikely that these discordant geochemical patterns reflect the lithologies of the sedimentary host rocks. We believe that regional transcurrent faults, crossfaults, geofractures, and joints were sites of alkalic igneous intrusions and deposition of titanium, REE, and associated minerals.

Map A shows the relationship of transcurrent-fault patterns to the distribution of lanthanum concentrations. The role of crosscutting faults as controls on mineral deposition is demonstrated by the radical departure of the lanthanum-isopleth trends from a northeast trend to one that is northwest, as shown in the outlined rectangular area (map B, tract A). Farther to the south, another northwest trend of lanthanum isopleths similarly departs from the northeast in a zone subparallel to the TransAppalachian fault zone of Woodward (1968). In both cases, these changes in trend of the regional isopleths to a northwest trend suggest that structures that crosscut the regional stratigraphic grain may be the underlying influence on the northwest trends shown by the lanthanumdistribution patterns.

The possible role of the regional northeast-trending transcurrent faults, both at the surface and in the basement (Woodward, 1968), as a control on mineralization is likewise indicated by the close correlation of the distribution of lanthanum anomalies to the orientation of transcurrent faults (map A). Areas where regional structural trends and crosscutting faults intersect are zones that contain high-contrast, multielement geochemical anomalies. One such intersection is in tract A; another area is located at about latitude $38^{\circ} 15^{\prime}$, longitude $81^{\circ} 15^{\prime}$ (map $\mathrm{B}$, tract L-2). Within that zone, a lanthanum anomaly outlines the intersection of the northeast-trending transcurrent faults with a nearly north-trending basement fault. We hypothesize that a favorable structural trap was provided by this intersection, which may have become a locus for the deposition of REE-Th-Ti minerals.

Another significant intersection of structural and geochemical trends is located at about latitude $38^{\circ} 30^{\prime}$, longitude $81^{\circ} 30^{\prime}$ on the Trans-Appalachian fault zone itself where it intersects several northeast-trending transcurrent faults (maps A and B). The stream sediments collected from the zone of intersection contained high concentrations of $\mathrm{Ce}$ and $\mathrm{Ti}$ (map B, tract $\mathrm{L}-1$ ). A favorable structural environment for mineral deposition is indicated by an increase in geochemical contrast.

\section{GEOCHEMICAL TRACTS}

Zones of geochemical anomalies (tracts) identified from the NURE stream-sediment data are delineated on map B. A detailed discussion of the tracts A, L-1, L-2, $B$, and C follows. Some characteristics that tracts A, L-1, $\mathrm{L}-2$, and $\mathrm{C}$ share are (1) nearly coextensive regional anomalies of $\mathrm{Ti}, \mathrm{REE}, \mathrm{Th}, \mathrm{Al}, \mathrm{V}, \mathrm{Fe}$, and $\mathrm{Mn}$, (2) strong gamma-ray and uranium anomalies (Bond and Duval, 1994), (3) gamma-ray anomalies in deep wells (Cardwell, 1982; Cannon and others, 1993), and (4) fluorine anomalies in well water. Supplementary USGS analyses of the NURE samples collected from tracts A and B revealed anomalous concentrations of several sulfideforming and pathfinder elements (Hinkle and others, 1994 a,c; Watts and others, 1992, 1994). Had there been supplementary analyses conducted on samples collected from the other tracts, we believe that additional chalcophile anomalies might have been found.

\section{TRACT A}

Tract A predominantly consists of REE-lithophile element anomalies accompanied by less areally extensive, low-contrast chalcophile-element anomalies. The tract includes two discrete anomalous areas (A-1 and A-2) whose geochemical characteristics and geologic setting differ somewhat (fig. 4).

The abundances of reported elements from the complete NURE data set from tract $A$ and selected elements from the USGS data set from tract A are summarized in figures 5 and 6 , and tabulated (for the full data sets) in tables 1 and 2. We used the mean of tract-A data as the approximate threshold value for these elements; thus, all values greater than the mean for tract $A$ could be significant.

The sedimentary units exposed in tract A are the coalbearing Conemaugh Formation and Monongahela Group, which contain less titanium than the stream sediments collected from the same area. The average titanium content of 
coal beds in the Monongahela Group within tract A (combined data from anomalies $\mathrm{A}-1$ and $\mathrm{A}-2$ ) is about 500-700 ppm, as calculated from percent $\mathrm{TiO}_{2}$ measured in coal ash (Zubovic and others, 1979, 1980). Emission spectrographic analysis of stream sediments in this area indicate an average of $7,492 \mathrm{ppm}$ titanium (Adrian and others, 1992); neutron activation analysis of the same NURE stream-sediment samples shows an average of $5,697 \mathrm{ppm}$ and a range to 6.2 percent. Our data indicate that the rocks of the Monongahela Group do not shed anomalous concentrations of titanium farther south along strike, although there are other linear northwest trends of anomalies similar to those in tract A (such as those in tract $\mathrm{L}-1)$ that crosscut the Monongahela Group.

Although coal is known to concentrate a variety of elements, comparison of published coal values with reported concentrations of several other metals in the stream sediments indicates that the source of the high concentrations of metals in stream sediments of tract A is probably not drainage basin coal beds. The mean values for all elements in stream sediments collected in tract A exceed those for coal ash, whereas coal ash maximums exceed those of stream sediments for $\mathrm{Cu}, \mathrm{Mo}, \mathrm{Ni}$, and $\mathrm{Sr}$ (figs. 7 and 8). Although molybdenum and nickel concentrations in stream sediment samples may reflect contributions from coal beds to the drainage basins, in anomaly A-1 the distribution patterns of high copper and strontium concentrations correlate areally and have similar geometry to the distribution patterns of high titanium concentrations (Watts and others, 1992; Watts and others, 1994). These similarities in anomaly distribution suggest a cogenetic relationship between the copper, strontium, and titanium anomalies.

R-mode factor analysis was run on a set of merged NURE and USGS data from anomalies A-1 and A-2 combined. The results (table 2) below are based on a fivefactor model. The five-factor model was established for these data through trial and error with other numbers of factors. It was found that a model of five factors produces suites of elements that account for much of the data variance and can be readily accounted for on the basis of known mineralogic and geochemical affinities. The mineralogic and geochemical implications of the associations are then used to infer the geologic and geochemical environment at the bedrock source of the metal anomalies.

Although the R-mode factor analysis was run on the combined set of data obtained from anomalies A-1 and $\mathrm{A}-2$, it is possible to infer which of the zones contribute the most to the element suites associated with each of the five R-mode factors. Considering the element suites associated with the five factors, we conclude the following. (1) Factor-1 element associations are largely a reflection of the sedimentary lithologies of rocks of the Monongahela Group sequence; the overlying and underlying rock sequence also contributes in a minor way. Coal beds may contribute many metals in this association, but we believe that some of the highest concentrations of these elements are due to mineralized source rocks. (2) The factor- 2 association relates to heavy detrital minerals contributed by many different sources. In anomaly A-1, the highest concentrations of these elements may have resulted from epigenetic processes. The association in anomaly A-2 is related to the sedimentary sequence near the contact between the Lower and Middle Pennsylvanian sequence and the overlying Conemaugh Formation and Monongahela Group. (3) Factor-3 associations indicate the presence of titanium minerals, zircon, and possibly tourmaline in the drainage basin source rocks. The association typifies anomaly A-1 and is one basis for proposing a subsurface diatreme within the area. (4) Factor 4 is a carbonate-mineral association that could be derived from epigenetic veins in anomaly A-1. (5) Factor 5 is a sulfide association that typifies the anomalouselement suite of anomaly A-1 (Watts and others, 1992, 1994; Hinkle and others, 1994a). The association of strontium and tin reflected in the factor- 5 suite is supported by the coextensive distributions of high concentrations of these elements with that of the elliptical-shaped titanium anomaly (fig. 9). The geochemical association of $\mathrm{Sr}-\mathrm{Sn}-\mathrm{Ti}$ has been noted in alkalic rocks, carbonatites, and related diatremes in many parts of the world, and is considered part of the evidence for the existence of such a body in the subsurface of anomaly A-1 (see discussions in later sections).

\section{Anomaly A-1}

Drainage-basin anomalies associated with anomaly A-1 cover an area of approximately $1,100 \mathrm{mi}^{2}$ within Harrison, Taylor, and Doddridge Counties (area delineated on map B). Anomaly A-1 is best defined by the distribution of anomalous concentrations of titanium (fig. 9). The isopleth pattern of delineating high concentrations of titanium has a northwest-trending long axis of about $38 \mathrm{mi}$ (Watts and others, 1992, 1994).

The rocks in the immediate area surrounding anomaly A-1 are deformed into northeast-trending open folds with frequent disruptions in strike, which are interpreted as crosscutting faults, geofractures, and joints that extend across the state from the Virginia to Ohio borders (Woodward, 1968). A zone of inferred transcurrent faults in the basement, parallel to the strike of the beds and extending into the area of tract A, is considered an eastward extension of the 38th-degree lineament of the midcontinent region (Woodward, 1968; Snyder and Gerdemann, 1965) and part of the New York-Alabama lineament (King and Zietz, 1978). To the north in Pennsylvania, two localities that contain mica peridotite dikes that intrude the coal measure sequence are structurally aligned with anomaly A-1 (fig.1). 
In Pendleton County, basalt, breccia, and albitite dikes are intruded into joint systems with orientation near $\mathrm{N} .45^{\circ} \mathrm{W}$. and are structurally aligned with anomaly $\mathrm{A}-1$ to the southeast (Garnar, 1956; Fullagar and Bottino, 1969; Dennison and Johnson, 1971; Rader and others, 1986). These are the only igneous rocks known in West Virginia. Comparable rocks in neighboring areas of Virginia have been radiometrically dated as young as Eocene, but most are probably of Triassic and Jurassic age. One of the two occurrences of mica peridotite in the Pennsylvanian coal measures near Masontown, Fayette County, Pennsylvania was dated at $185 \mathrm{Ma}$ (Pimentel and others, 1975) and 188-175 Ma (Zartman, 1977), whereas the other occurrence at Dixonville, Pennsylvania, in Indiana County has not been dated to our knowledge. Both of the Pennsylvania occurrences of mica peridotite dikes are located on the flanks of the Chestnut Ridge anticline (Honess and Graeber, 1924, 1926). This same anticline passes through the area of anomaly A-1 and turns sharply eastward near the town of Bridgeport (Cardwell, 1982) at about the point where geochemical anomalies begin to appear (Watts and others, 1992, 1994). Axial depression and high-angle faulting on the flanks of the Chestnut Ridge anticline as described to the north in Fayette and Westmoreland Counties, Pennsylvania (Gwinn, 1964) could be the result of diatreme-related doming; this postulate certainly warrants investigation.

The positive correlation coefficients between key elements (table 3) illustrate some of the geochemical associations of key elements in anomaly A-1.

Several characteristics of anomaly A-1 may be useful for the assessment of mineral potential within this zone. The most salient characteristics are summarized below.

(1) The zone of geochemical anomalies crosses the boundary between Dunkard Group rocks to the west and the Monongahela Group rocks to the east, although most of the area encompassed by the zone is underlain by rocks of the Monongahela Group. The possibility that this zone may have provided permeable pathways for mineralizing solutions, or otherwise controlled mineral deposition might be a consideration.

(2) Anomaly A-1 is located on the southern margin of the Silurian evaporite basin as interpreted from drill holes (King and Kirstein, 1987), which also is a favorable criteria. There are many ramifications to having evaporite beds at the surface, not the least of which is the possibility for mineralizing solutions to evolve from these evaporite deposits.

(3) The structural setting of anomaly A-1, situated as it is at the intersection of northeast-trending transcurrent faults and crosscutting northwest structures, could have formed a dilatant structural environment that was favorable to the movement upward of any hydrothermal fluids that might have been available. In addition, this zone of weakness could have localized alkalic igneous activity. The presence of alkalic igneous rocks to the north and to the southeast of anomaly A-1 on these same intersecting structures is a favorable condition for similar type igneous activity within the area of anomaly A-1. The Chestnut Ridge anticline also could be a key structural control on mineralization in anomaly A-1.

(4) Anomalous REE, lithophile, and chalcophile elements form elliptical and linear isopleth patterns within, and on the periphery of, the titanium ellipse that defines the boundary of anomaly A-1 (Watts and others, 1992, 1994). The geometry of these distribution patterns of high elemental concentrations indicate structural control on the distributions.

(5) Gamma-ray anomalies were found in the subsurface of anomaly A-1 (Cannon and others, 1993; Cardwell, 1982). Alkalic igneous bodies are characterized by gamma-ray anomalies.

(6) Two aeromagnetic highs are located on the outer periphery of anomaly A-1 (King and others, 1993), nearly coincident with the highest titanium zones. Magnetic anomalies characterize diatremes and alkalic igneous bodies, although they are not uniquely diagnostic.

(7) Fluorine anomalies in well water (NURE data) follow the trend of the northwest-trending structures and coincide with zones of high titanium concentrations, particularly on the southern lobe of the titanium ellipse delineating anomaly $\mathrm{A}-1$.

The above-listed characteristics strongly suggest that the discordant ellipse formed by titanium isopleths in anomaly A-1 is the result of either leakage from a subsurface diatreme or a carbonatite associated with a mafic intrusion in the basement. Theses conclusions are supported by the type of geochemical association $(\mathrm{Ce}, \mathrm{La}, \mathrm{Sr}$, $\mathrm{Ba}, \mathrm{Mn}, \mathrm{Cu}, \mathrm{Pb}, \mathrm{Au}$, and $\mathrm{Sn}$ ), which is known to characterize the diatreme environment (Olson and others, 1954; Erickson and Blade, 1963; Baldock, 1969) and by the regional tectonic setting that favors the intrusion of alkalic igneous bodies (Grogan and Bradbury, 1968; Snyder and Gerdemann, 1965; Zartman, 1977). Detailed discussion of the diatreme model and the geochemical data for anomaly A-1 can be found elsewhere (Hinkle and others, 1994a-c; Watts and others, 1992, 1994). Adrian and others (1992) list the supporting chemical data.

\section{Anomaly A-2}

Anomaly A-2 in tract A (fig. 4) is characterized by widespread higher than average concentrations of $U$, Th, $\mathrm{Ce}, \mathrm{Hf}$, and La (NURE data), accompanied by scattered anomalies of $\mathrm{Au}, \mathrm{Cr}, \mathrm{Zn}$, and $\mathrm{Sn}$ (USGS data). The mapdistribution patterns of these elements are broadly coextensive, but zoned. The element association typifies heavymineral affiliations and suggests that the high element 
concentrations are due to placer accumulation. The distribution pattern of hafnium, which nearly always occurs in zircon, broadly delineates the outer limits of the anomalous zone. A mutual source environment of the elements involved in this anomaly is suggested by the manner in which the map-distribution patterns of nearly all elements involved straddle the contact of Monongahela Group rocks with the underlying Middle Pennsylvanian units in a northeast trend that parallels regional strike of the beds. From this distribution pattern we infer that the source of these anomalies is a contact zone or unconformity at the base of the Monongahela Group.

The bedrock sources of these anomalies are probably enriched above background concentrations and thereby provide a rich source of the heavy minerals present in the drainage-basin alluvium. Source-rock environments for these stream-sediment placers could be (1) fossil placers accumulated in beds near the base of the Monongahela Group and (2) minerals deposited hydrothermally or by ground water along intraformational reduction-oxidation interfaces.

The degree of association of uranium with key elements in anomaly A-2 is shown below by productmoment correlation analysis (all of these correlations are statistically significant at the 99th-percentile confidence level). The correlation analyses show that uranium is more closely associated with REE in anomaly A-2 than it is with REE in the state as a whole.

The correlation coefficients listed in table 5 relate the key element associations found throughout the state to anomaly A-2 for comparison. The interpretive implications of each key element listed are as follows: (1) titanium represents the lithophile anomalies; (2) cerium represents the REE-Th anomalies; (3) iron and manganese relate to secondary Fe-Mn oxides; and (4) copper represents the chalcophile elements.

\section{TRACT B}

Tract B is within the Valley and Ridge Province of West Virginia and constitutes a geochemical and geological terrane separate from the other anomaly tracts in West Virginia. Tract B is predominantly a base-metal anomaly, characterized by anomalous concentrations of $\mathrm{Fe}, \mathrm{Mn}, \mathrm{Zn}$, $\mathrm{Cu}, \mathrm{Ba}, \mathrm{Pb}, \mathrm{Mo}, \mathrm{As}, \mathrm{Co}, \mathrm{Ni}, \mathrm{Cd}$, and Sb (figs. 10-17). Of the elements found to be anomalous in tract $\mathrm{B}$, arsenic, cadmium, and antimony are moderately diagnostic indicators of sulfide mineralization. The predominant mechanism for concentrating these metals in rocks is through hydrothermal mineralization. Thus, if arsenic, cadmium, and antimony are found in anomalous concentrations, it is a good indication that ore-forming processes have gone on in the area of these anomalies. Cadmium in particular is almost never seen without the presence of sphalerite (the chief ore metal of zinc) nearby. Arsenic, on the other hand, is highly susceptible to sequestering in secondary iron oxyhydroxides, but there must be an enriched bedrock source to make available a significant amount of the metal to form secondary concentrations. In sedimentary rocks, antimony is usually found in sulphosalt minerals in epigenetic and sedimentary-exhalative environments of mineralization, and is practically nonexistent in unmineralized rocks. Although both cadmium and antimony are slightly enriched in stream sediments of tract B, arsenic, which is in higher concentrations above background and is more widespread than the other two metals, serves to represent the group on the map plots.

Map plots (figs. 12-17) of the key elements show that the distributions of higher than normal concentrations follow the stratigraphic trends of the lower Paleozoic shale and sandstone units. The distribution pattern of combined elements in tract B (fig. 12) broaden within the center of the anomaly zone in conjunction with an increase in both geochemical contrast and the number of anomalous elements. The broadening of the pattern could be due to folding of the beds that host the metals, thereby exposing more of the metalliferous horizon(s) at the surface. The pattern terminates abruptly to the west at the DevonianMississippian unconformity. The multielement anomalies form a much narrower pattern southward, suggesting that mineralization may pinch out in that direction. The northward broadening of the pattern suggests that the anomaly continues into those areas where supplementary USGS data are lacking.

Several old state reports mention that traces of galena are widespread in the Devonian Chemung Formation, which is composed of siltstone, sandstone, and shale; there is also one mention of galena in the underlying formation. Minor disseminated lead in the Devonian strata may account for some of the anomalous concentrations of lead in Pendleton County and counties to the north, but this cannot account for the broadest lead anomaly, which extends westward from Mooresville. In this area west of Mooresville, an anticline brings Silurian-age rocks of the Clinton Formation to the surface. Only farther west does a syncline bring the Devonian rocks down to the present surface. The sources of the lead anomalies in tract B therefore must be in rocks older than the Devonian Chemung Formation.

An understanding of metal partitioning of the anomalous metals in the different mineral phases of the stream sediments is useful to better evaluate the significance of the stream-sediment anomalies. The partial-extraction (ICP-AES) technique used on samples collected from tract $B$ is specific for sulfide-forming elements. By excluding the metal content of the stream-sediment samples held in the silicate lattices of common rock-forming minerals, the technique focuses on the metal content related to sulfide minerals, secondary iron-manganese oxides, and other more readily soluble minerals whose sources could be 
mineralized drainage-basin bedrock. In contrast, the ES analysis gives an estimate of the total metal content of a sample, including the lattice-held metals. Therefore, a comparison of the amount of metal content extracted by the ICP-AES method with that reported from the ES method provides an estimate of proportion (in each sample) between metals held in sulfides and secondary oxides, and metals held in the silicate lattices. Many stream-sediment samples collected from tract B contain anomalous concentrations of chalcophile metals on the basis of the ICP-AES analysis, indicating that sulfide minerals and secondary gossan materials could be widespread in drainage-basin bedrock of the area.

The ICP-AES data also show the proportion of each metal that is retained in the secondary iron-manganese oxyhydroxides, both of which are known to scavenge oreforming elements. Some elements, such as arsenic, usually concentrate in the iron phases of the secondary oxides, whereas other elements, such as zinc, usually prefer manganese. The proportion is evaluated by correlating iron-metal pairs and manganese-metal pairs from the partial extraction (ICP-AES). The portion of the metals associated with discrete iron- and manganese-silicate minerals can be evaluated using iron-metal and iron-manganese correlation pairs based on the total analysis (ES) data.

From correlating the key anomalous metals with each other and between the different mineral phases represented by the different types of analyses (fig. 18) come the following observations: (1) $\mathrm{Zn}$ closely correlates with $\mathrm{Cu}$, $\mathrm{Mo}, \mathrm{As}, \mathrm{Sb}, \mathrm{Cd}$, and $\mathrm{Ni}$, indicating that sulfide-mineral deposits are present in tract $\mathrm{B}$; (2) copper and zinc are present in the stream sediments within iron and manganese oxides, with respect to partitioning copper closely associated with iron oxides, whereas zinc is more closely associated with manganese oxides; (3) lead is associated with iron and manganese oxides about equally; (4) molybdenum is not associated preferentially with either iron or manganese, but is strongly associated with zinc; (5) arsenic correlates slightly better with iron oxides than those oxides dominated by manganese, which is consistent with its known geochemical behavior; and (6) antimony and cadmium do not correlate well with the ironmanganese oxides, which suggests that they are found in discrete minerals not readily attacked by the digestive process used in the preparation of samples for the ICP-AES analysis.

Much of the iron in stream sediments collected in tract B probably originated from pyrite in mineralized rocks where it is associated with chalcophile elements, although detrital iron and manganese are also present. Barium and iron deposits are present in and around tract $B$, and zinc and fluorite deposits are located nearby. Most sediment samples that contain the highest concentrations of manganese were collected in streams that drain undivided Devoniarı rocks.
Hematite is a component of lower Paleozoic iron formations in area B. Iron also is present in pyrite and is a minor component of carbonate minerals. Iron oxide and oxyhydroxide mineral particles derived from the weathering of these materials are washed into the streams and form part of the sediments that were sampled. The iron oxyhydroxides readily adsorb other metals during and after their formation. Small amounts of galena and sphalerite found in trace amounts in the Paleozoic rocks provide anomalous concentrations of $\mathrm{Pb}$ and $\mathrm{Zn}$, that can be accompanied by $\mathrm{Cd}, \mathrm{Ge}, \mathrm{Ga}$, and other metals. Background concentrations of $\mathrm{Co}, \mathrm{Ni}, \mathrm{Cr}$, and other trace metals in the shale and carbonate rocks reach concentrations in the oxyhydroxides that are far higher than in the source rocks.

Manganese minerals are not known to be present in unweathered rocks, but traces and minor amounts of the metal are widespread in the shale and carbonate sedimentary rocks of tract B. A large number of black manganese oxide and oxyhydroxide minerals accumulated residually during weathering of the rocks. Several zones of these minerals have been found in the southern Appalachians. The black manganese-bearing minerals formed moderately pure concretions as well as thin films on sand grains. In the latter form, they actively adsorb other metals in the same manner as the iron oxyhydroxides.

A combined set of all available stream-sediment geochemical data for tract B was examined by R-mode factor analysis using a 5-factor model (table 6) in order to better understand the composition of the stream sediments collected from the area. The resultant element associations that emerge from the R-mode factor analysis are considered to have the following significance. Factor 1 reflects the rock-forming minerals present in the drainagebasin alluvium. As a result, the drainage-basin lithologies influence the concentrations of elements in the factor-1 suite. Factor 2 is the most significant element suite in tract $B$. The factor- 2 suite elements include the anomalous chalcophile association of nonchalcophile elements that characterize tract B; and therefore high scores in this factor may be related to mineral deposits in the drainagebasin bedrock. The factor-3 association of $U$, Th, and REE is probably due to heavy detrital minerals within the drainage basin alluvium. The significance of this association and any high concentrations of the elements in the factor3 suite could be similar to the significance proposed for anomalies of these elements in tract A. Factor-4 element associations are directly related to the contribution of carbonate minerals to the drainage-basin alluvium. In general, this factor can be regarded as a direct indication of the presence of carbonate bedrock in the drainage basin. On the other hand, carbonate gangue minerals from veins or chemical sedimentary rocks could also contribute to the element suite constituting factor 4 . The element suite constituting factor 5 also is related to heavy detrital minerals, 
as proposed for factor 3 . In the case of factor-5, on the other hand, a different assemblage of heavy minerals dominated by zircon is suggested.

For the purpose of comparison with the other tracts of geochemical anomalies shown on map B in which USGS data are lacking, the tract B NURE data alone was examined by product-moment correlation analysis. Associations revealed by high positive-correlation coefficients between element pairs facilitates interpretation by providing insights into stream-sediment compositions not obvious from visual scans of the data.

The high positive correlation for the titanium-aluminum pair is caused by the close geochemical affinity of the two metals. High positive correlation between lanthanum and titanium indicates that, in tract $B$, as elsewhere in West Virginia (map A), that titanium- and lanthanumrich heavy minerals occur together in the drainage-basin alluvium and may have the same bedrock sources. The correlation coefficients show also that other REE are involved in the associations of lanthanum in tract $B$.

The map of titanium in stream sediments of West Virginia (Watts and others, 1994) shows a zone of high titanium concentration in tract $B$ that is coextensive with the main zone of chalcophile-element anomalies of figure 12 . The association of titanium concentrations with the chalcophile-element anomalies could be significant; it might indicate that alkalic igneous and geothermal activity introduced metals to, or remobilized metals from, the sedimentary rock units in the titanium-enriched portion of tract $B$.

Our overall interpretation is that most of the anomalies in tract B are from sulfide and Fe-Mn oxide mineral occurrences in the drainage-basin sedimentary rocks. The characteristics of the geochemical anomalies and the geology indicate the presence of stratabound deposits in the folded sedimentary rock sequence, possibly of the sedimentary-exhalative type. At least locally, within the area of highest chalcophile element concentrations, high concentrations of titanium and REE indicate that late geothermal and alkalic igneous activity may have superimposed a second geochemical signature on the area.

\section{TRACT L-1}

The third tract that warrants further examination is a broad linear pattern of anomalies that transects the regional strike of sedimentary beds at nearly right angles and the trends of fold axes at about the same angle as the Trans-Appalachian fault zone of Woodward (1968). The highest titanium concentrations of this zone are largely within the rocks of the Dunkard Group. Titanium concentrations in this tract are even higher than those in anomaly A-1 in tract A (fig. 19).

Product-moment correlation analysis indicates that there are no significant correlations between titanium and the other elements of the NURE data set, even though titanium is highly concentrated in the stream sediments of tract $\mathrm{L}-1$ and is broadly distributed areally. A similar statistical relationship between titanium and other elements in the NURE data set is present in anomaly A-1, tract A. This lack of statistical association of titanium with other elements may be attributable to zonal element distributions within the tracts of anomalies, perhaps related to mineralization patterns.

There are, on the other hand, significant correlations of elements in the NURE data set (table 8) with the key elements iron and manganese (representing possible sulfide occurrences), and cerium (representing the REE) that provide a clue to the geochemical environment of tract $L-1$.

As an example, the positive correlations of iron and manganese with aluminum indicate that the coprecipitation of amorphous iron-manganese oxyhydroxides and clay in the stream environment is a significant process in the concentration of these metals in the stream sediments of tract L-1. The presence of highly acid water could result in such a stream environment. Acid water can develop as the result of a variety of surficial processes, but sulfide oxidation is one of the most important.

As another example, a scan of the positive correlations of table 8 shows, predictably, that cerium is associated with $\mathrm{U}$, Th and other REE in tract L-1. Table 8 shows that REE are associated with iron to a greater extent than with manganese or aluminum, suggesting that some iron concentrations could have a separate source from those of manganese and aluminum, and are not solely the result of precipitation in the stream beds. One possibility is that iron and REE were concentrated in the stream alluvium as the result of downslope mechanical migration of REErich limonite from weathered mineralized zones in the drainage-basin bedrock.

The distribution patterns of the stream-sediment anomalies in tract $\mathrm{L}-1$ provide some indication of possible bedrock sources. The anomaly pattern of titanium in tract L-1 is nearly continuous (Watts and others, 1994) and almost exactly coincides with the regional distribution pattern of anomalous concentrations of lanthanum, nearly coincides with that of cerium, and is similar to, but slightly displaced from, that of manganese. For the regional distribution of cerium and lanthanum, see other maps in this series (Hinkle and others, 1994a,c). Radiometric anomalies (Bond and Duvall, 1994) and fluorine anomalies in well water are also present within the northwestern extremity of the tract. The southeastern extremity of tract $L^{-}-1$ encompasses Pendleton County where outcrops of mafic alkalic dikes have been found (Garner, 1956). Thus, the titanium anomalies in tract $\mathrm{L}-1$ could indicate the presence of unrecognized igneous dikes emplaced along a fracture system whose orientation is similar to the known dike systems in Pendleton County and in Virginia. 
Two areas of tract L-1 (map B) are the best targets for further investigation: (1) the area adjacent to the state border that contains strong overlapping cerium-titanium anomalies and (2) the area that contains the large cerium high at the intersection of the proposed Trans-Appalachian fault trend (Woodward, 1968) and the east-northeast-trending transcurrent faults near latitude $38^{\circ} 30^{\prime}$, longitude $81^{\circ}$ $30^{\prime}$. Of the two areas, the second may be the more significant because of its unique structural and geochemical characteristics. The rocks of the structural intersection might have been highly permeable, allowing movement of mineralizing fluids, and concomitant dilation could have been conducive to the deposition of REE-, Ti-, Th-, Fe-, and Mn-rich minerals.

\section{TRACT L-2}

The geochemical anomalies of tract L-2 crosscut the stratigraphic section, but they are most prominent in the Monongahela Group, particularly near the contact with overlying Dunkard Group rocks. Tract $\mathrm{L}-2$ has similar characteristics to tracts $\mathrm{A}$ and $\mathrm{L}-1$ that include gammaray anomalies in wells and fluorine anomalies in well water, as well as radiometric anomalies (detected during airborne surveys).

The basis for delineating tract $\mathrm{L}-2$ is the combined regional distribution of higher-than-median concentrations of lanthanum and cerium. Cerium isopleths within tract L-2 show the general distribution patterns of REE anomalies. Thorium is also associated with the REE anomalies, but its regional isopleth pattern has a slightly different northwest orientation (Hinkle and others, 1994c). A northtrending transcurrent fault in the basement coincides with the trend of the cerium isopleths shown in tract L-2.; thus, the transcurrent fault zone may have localized the deposition of REE minerals. REE concentrations increase within the area where the north-trending subsurface transcurrent fault intersects a zone of northeast-trending faults. The lanthanum distribution patterns on map A clearly show an increase in concentration within the area of structural intersection as well as an intersection of isopleth trends. The area could have been the locus of mineral deposition and is the most promising area to begin follow-up field investigation within tract $\mathrm{L}-2$.

\section{TRACT C}

The map plot of lanthanum isopleths in the area of tract C (map A) suggests that regional trends of the anomalies are northwest and north in orientation. The intersection of these lanthanum-isopleth trends in tract $\mathrm{C}$ (about latitude $38^{\circ} 15^{\prime}$, longitude $82^{\circ} 00^{\prime}$ ) is characterized by an increase in concentrations of lanthanum (map A) and a coincidence with a northeast-trending transcurrent fault.
As is the case with tracts $L-1$ and $L-2$, little is known about possible chalcophile associations in the area because data are lacking. Known features of the tract include the following: (1) the anomalies are mostly restricted to rocks of the Monongahela Group and include the usual Al-Mn-Th-Ti-REE suite; cerium concentrations are particularly high near the state border; (2) gamma-ray anomalies are present in the subsurface in the southeastern corner of the tract (Cannon and others, 1993); (3) radiometric anomalies (detected during airborne surveys) are in the northeastern corner of the tract (Bond and Duval, 1994); and (4) roughly linear north-trending zones of fluorine anomalies occupy the southeastern and northwestern corners of the tract.

\section{METALS IN COAL}

Coal commonly contains many metals that were either present in the original organic matter or adsorbed from ground water. The potential of coal to contain high concentrations of metals suggests that local coal units might be the sources of metal anomalies in stream sediments. Disturbed ground in mining areas exposes coal seams to weathering, thus particles of coal would be included in stream-sediment samples. Water samples collected from several streams that drain coal mining areas have anomalously low $\mathrm{pH}$ levels due to the oxidation of pyrite to sulfuric acid in the spoil piles. Acid would help mobilize metals contained in the coal units, and dissolved metals would then precipitate or adsorb on stream sediments when the dissolved metals encountered higher $\mathrm{pH}$ waters.

Although the coal units of West Virginia contain many different elements, no relationship has been established between metal concentrations in coal beds and metal anomalies in stream sediments. Concentrations of metals in tract A stream sediments exceed concentrations of metals in coal by as much as ten times. Coal has been mined in this area for many years. If acidic stream waters were leaching metals from coal units and alkaline stream waters were precipitating metals, sediments in streams with the highest $\mathrm{pH}$ values should contain the most metals. This effect should be especially notable in those mining districts where powdered limestone is used to reduce the potential for coal-dust explosions; streams draining these areas often have higher than average $\mathrm{pH}$ and alkalinity (Borchers and others, 1991).

Several stream-sediment samples collected within tract $B$ in the northeastern part of the state contained anomalous concentrations of metals. However, most of this area is barren of coal; existing mines have produced less than 10 percent of the statewide tonnage (Barlow, 1974). Therefore, the possibility that stream-sediment metal anomalies originated from coal deposits in this area is remote. 
Sulfur in coal occurs primarily as pyritic and organic sulfur. The source of iron for pyrite would be detrital magnetite in the sediments surrounding the coal. Weathering high-sulfur coal could form metal sulfides. Coal beds in northwestern West Virginia have the highest sulfur content (about 3 percent) in the state, whereas coal beds in the south-central part of the state contain less than 1.5 percent sulfur (Barlow, 1974). If iron and other metals were associated with sulfur in coal as metal sulfides, then most of the metal anomalies would be located in the northwestern part of the state; however, this is not the case.

\section{CONCLUSIONS}

We prefer to invoke a mechanism other than normal basin sedimentation to explain the existence of transgressive geochemical anomalies in the coal-basin areas of the western to northwestern part of West Virginia. Moreover, we do not consider coal or high-background lithologies to be the predominant sources of high-contrast stream-sediment anomalies anywhere in the state. Within the coal basin areas, it can be argued that if these geochemical signatures are typical of the Pennsylvanian and Permian rocks, the geochemical isopleths should parallel the regional strike of the beds. The regional distribution patterns of manganese, vanadium, and iron at low to moderate concentrations in stream sediments parallel the regional strike of the sedimentary rock sequence, but diverge from parallelism at the highest levels of concentration. Thorium and REE anomalies are also oriented parallel to the strike of beds, but the close spatial relationship of these anomalies to the set of transcurrent faults in the western part of the state indicates structural rather than lithologic control. There is, on the other hand, a close geochemical association with the stratigraphic sequence in tract $\mathrm{B}$. Within tract $\mathrm{B}$, however, the sources of the high-contrast chalcophile-element anomalies are from mineralized sedimentary host rocks, not normal lithologies.

We consider the discordant (transgressive) element anomalies within the state (which are almost entirely in the western and northwestern half of the state) to be related to alkalic igneous activity and related Ti-REE mineralization. The proposed mineralization may be geologically controlled by a combination of (1) northeasttrending transcurrent faults, (2) northeast-trending anticlines (for example the Chestnut Ridge anticline), (3) northwest-trending fractures, crossfaults, and related alkalic dike systems, and (4) larger, but related, alkalic bodies and diatremes.

The linear, discordant trends of high titanium and REE concentrations are oriented northwest in general, but the orientation varies in specific tracts from west-north- west (tracts L-1 and C) to northwest (tract A) to north (tract L-2). We suggest that these differences in orientation have an underlying structural control related to rightlateral movement on the northeast-trending transcurrent faults that cross West Virginia. Furthermore, according to our interpretation, the transcurrent fault movement has created conjugate faults and fractures parallel to the orientation of the geochemical-anomaly trends, which have controlled the intrusion of mafic, alkalic igneous bodies and related mineralization. The orientation of the geochemical-anomalies accordingly results from shifts in tectonic-stress orientation with time, and possibly from second-order conjugate shear (for example, the orientation of geochemical trends in tract $\mathrm{L}-2$ ). If alkalic igneous dikes are found in the anomaly tracts, age dating of the pertinent rocks could help resolve questions regarding these shifts in orientation.

There are two mineralized alkalic complexes that we wish to describe because they seem to be appropriate models for anomaly A-1 (tract A), as well as the structural and geochemical intersections in tracts $\mathrm{L}-1, \mathrm{~L}-2$, and $\mathrm{C}$. The first of these models is Hicks dome in southern Illinois where fragments of Precambrian material were carried explosively upward 8,000 feet into the overlying coal measure sequence (Snyder and Gerdemann, 1965 , p.466). The formation of diatremes in southern Illinois and southeastern Missouri began with the intrusion of alkalic magma into the Precambrian basement during the late Paleozoic. Intrusion was then followed by gas buildup and violent explosion during the Permian, raising the stratigraphic section thousands of feet vertically and bringing rock fragments upward. Afterwards there was intrusion of mafic and ultramafic dikes followed by fluorite-sulfide mineralization (Grogan and Bradbury, 1968; Snyder and Gerdemann, 1965). Studies of the fluorite-base metal mineralization in the area have demonstrated that the distance that metals can travel in a convecting saline fluid driven by a heat source given ample fracture permeability of the host rocks can be considerable. The analogies of Hicks dome with the geochemical tracts in West Virginia consist of similarity in anomalous geochemical suite and geologic setting. Hicks dome has been dated (by $\mathrm{K}-\mathrm{Ar}$ method) at 281-258 Ma (Zartman, 1977) and is only one of many diatremes and mafic-ultramafic rocks that cut Pennsylvanian sediments and coal measures in the midcontinental region (Snyder and Gerdemann, 1965; Zartman, 1977).

The second possible model is Magnet Cove in the Ouachita basin of Arkansas. The supplementary geochemical data available for anomaly A-1 of tract A presents geochemical characteristics that are strikingly similar to those of Magnet Cove, Arkansas (Erickson and Blade, 1963). The Magnet Cove titaniferous deposit is associated with an alkalic igneous-carbonatite complex intruded into folded and faulted Paleozoic rocks. Localization of 
igneous emplacement was at the abrupt change in strike of major structural elements, as we proposed for anomaly A-1. As at Hicks dome, there is structural evidence of explosive activity at Magnet Cove (Erickson and Blade, 1963). The titanium minerals at Magnet Cove include rutile, brookite, perovskite, anatase, and sphene, all of which are present within veins mostly hosted by carbonatite. The complex is characterized by abundant barium-, strontium-, and cerium-group REE minerals, and anomalous concentrations of manganese, vanadium, base metals, and tin held within the structures of oxide and sulfide minerals. The anomalous concentrations of tin at Magnet Cove are found in $\mathrm{Zr}$-rich minerals and the titanium minerals rutile and brookite. By analogy with the reported occurrences of tin at Magnet Cove, the moderately anomalous tin, titanium, and zirconium contents of some samples collected from anomaly A-1 provide a significant indication that the Magnet Cove model might be appropriate (Watts and others, 1992; also see other maps in this series).

The distribution of anomalous metals in tract B is more reminiscent of that found in the Appalachian Mountains south and east of West Virginia. Accordingly, comparable hydrothermal processes probably were at work there. Consequently, we believe that the sources of the anomalies in tract B are stratabound sulfide deposits in the lower Paleozoic sequence, although there is some support for metallization in tract B related to known geothermal activity in the eastern part of the state; anomalous concentrations of titanium and REE near the center of tract B (Hinkle and others, 1994a,c; Watts and others, 1994) could be the result of this late hydrothermal and igneous activity.

If there has been late hydrothermal activity, it is not necessary to look at sedimentary formations exposed at the surface as the only prospective hosts for ore deposits. There exists in the subsurface a substantial thickness of source beds from which metals may have been leached and perhaps redeposited in higher concentrations farther along on the fluid paths. This leaching and deposition would be more likely to take place under the Cumberland Plateau where there is a supply of brine in the Silurian strata that may aid in mobilizing metals and where there is a great thickness of younger rocks in which metals might be either dissolved or precipitated. The marked variation of the sedimentary rock facies indicates strong spatial variations in oxidation states, which provides an excellent environment for inducing precipitation of a variety of metals.

Some of the tracts discussed in this report may have been mineralized by lateral movement of solutions over short to moderate distances not exceeding a few tens of miles. Farther west in the area between the Appalachian and Rocky Mountains, major mineralized districts are located on the flanks of broad uplifted domes, apparently resulting from movement of solutions along acquifers for distances of many tens or hundreds of miles. In West Virginia, the largest of the midcontinent sedimentary basins abuts the uplifts of the folded Appalachians. This is different from the tectonic environments farther west, but it is probable that the dominant genetic factor is the presence of mineralizing solutions escaping toward the margins of the basins. This eastern edge of the Paleozoic basin has not been very well explored.

The regional-scale southwestward fingering out of the beds of the Devonian age Catskill delta is located partly in West Virginia, involving the Hampshire and Chemung Formations, among others. The general setting is reminiscent of the metal deposits of the Belt Supergroup of the western United States, which are found at the distal ends of beds in a broad Proterozoic delta. The reported occurrences of lead and zinc minerals in the Chemung Formation in several places suggests that a comparable mineralizing process may have taken place in eastern or central West Virginia.

\section{RECOMMENDATIONS}

We recommend further study of tracts $A, L-1, L-2$, and C. The specific goals of this study should include the following items.

(1) Follow-up field study to identify the immediate bedrock sources of titanium and associated elements in the drainage basins that have been shown to contain anomalies of these elements. This should involve followup sampling employing heavy-mineral concentrates to identify bedrock sources of titanium. Location of specific areas of bedrock sources should be followed by an investigation to locate igneous dikes, extensive brecciation, veins and stringers containing sphene, perovskite, rutile, ilmenite, leucoxene, REE minerals, unusual zirconiumbearing minerals, fluorite, barite, hematite, carbonate minerals, strontium-bearing minerals, base and precious metals, and any other evidence that would indicate fenitization of the country rocks. The detailed follow-up in bedrock areas might be accompanied by sampling of soils and saprolite where appropriate.

(2) Search drill-hole records for reports of the presence of unusual mineral occurrences, igneous rock types, brecciated host rock, faulting, fracturing, and brecciation with carbonate or hematite stringers that would indicate explosive structural disturbances and(or) fenitization of the country rock.

(3) Conduct ground magnetic surveys in the various tracts with priority on anomaly A-1 in tract A. Carbonatites, mafic-ultramafic rocks, and associated magnetite veinlets should produce strong local peaks. 
(4) Investigate alluvium for possible economic placer accumulations of $\mathrm{Ti}, \mathrm{REE}, \mathrm{Th},(\mathrm{Au})$, and (Sn) within the areas of Ti-REE anomalies, particularly in areas where linear isopleth patterns intersect.

(5) Tract B should be investigated for possible stratabound base-metal deposits associated with barite. Follow-up investigations should include more detailed collection of stream-sediment samples and heavy-mineral concentrates. Specific small drainage-basin areas identified by this follow-up study should then be systematically explored by sampling rocks and soils to identify zoning characteristics of the sedimentary exhalative metal suite $(\mathrm{Pb}, \mathrm{Zn}, \mathrm{Cu}, \mathrm{As}, \mathrm{Ba}$, and $\mathrm{Mn})$. This geochemical work must be accompanied by, and integrated with, a detailed study of the Paleozoic stratigraphy, paying particular attention to lateral facies changes.

\section{REFERENCES}

Adrian, B.M., Hinkle, M.E., Hopkins, R.T., Jr., and Motooka, J.M., 1992, Analytical results and sample locality maps of stream-sediment, stream water, well water, and spring water samples from the state of West Virginia: U.S. Geological Survey Open-File Report 92-331, $11 \mathrm{p}$.

Arkle, Thomas, Jr., 1974, Stratigraphy of the Pennsylvanian and Permian systems of the central Appalachians, in Briggs, Garrett, ed., Carboniferous of the southeastern United States: Geological Society of America Special Paper 148, p. 5-29.

Baldock, J.W., 1969, Geochemical dispersion of copper and other elements at the Bukusu carbonatite complex, Uganda: Transactions of Institution of Mining and Metallurgy, v. B, p. B12-B28.

Barlow, J.A., 1974, Coal and coal mining in West Virginia: West Virginia Geological and Economic Survey, Coal Geology Bulletin 2, 63 p.

Bond, K.R., and Duval, J.S., 1994, Potassium, uranium, and thorium gamma-ray maps of West Virginia: U.S. Geological Survey Miscellaneous Investigations Series Map I-2364-I.

Cannon, W.F., Clark, S.B.H., Lesure, F.G., Hinkle, M.E., Paylor, R.L., King, H.M., Simard, C.I.M., Ashton, K.C., and Kite, J.S., 1993, Mineral resource assessment of West Virginia: U.S. Geological Survey Miscellaneous Investigations Series Map I-2364-A, scale 1:500,000.

Cardwell, D.H., 1982, Oil and gas report and map of Doddridge and Harrison Counties, West Virginia: West Virginia Geological and Economic Survey Bulletin B-16-A, 55 p.
Cardwell, D.H., 1976, Geologic history of West Virginia: West Virginia Geologic and Economic Survey, 64 p. (educational series).

Cardwell, D.H., Erwin, R.B., and Woodward, H.P., comps., 1968, Geologic map of West Virginia: West Virginia Geological and Economic Survey, scale 1:250,000.

Cook, J.R., 1981a, Charlottesville $1^{\circ} \times 2^{\circ}$ NTMS Area, Virginia and West Virginia; data report (abbreviated); hydrogeochemical and stream sediment reconnaissance: Aiken, South Carolina, E.I. du Pont de Nemours, Savannah River Laboratory, Report No. GJBX-175-81, 17 p.

Cook, J.R., $1981 \mathrm{~b}$, Bluefield $1^{\circ} \times 2^{\circ}$ NTMS Area, Virginia, and West Virginia data report (abbreviated); Hydrogeochemical and stream sediment reconnaissance: Aiken, South Carolina, E.I. du Pont de Nemours, Savannah River Laboratory, Report No. GJBX-234-81, 17 p.

Cook, J.R., Fay, W.M., and Sargent, K.A., 1982, Delaware, Maryland, Virginia, and West Virginia data report (abbreviated); Hydrogeochemical and stream sediment reconnaissance: Aiken, South Carolina, E.I. du Pont de Nemours, Savannah River Laboratory, Report No. GJBX-103-82, 45 p.

Darton, N.H., and Diller, J.S., 1890, On the occurrence of basalt dikes in the upper Paleozoic series in central Appalachian Virginia: American Journal of Science, $v$. 39-40, p. 269-271.

Davis, J.C., 1973, Statistics and data analysis in geology: New York, John Wiley and Sons, $550 \mathrm{p}$.

Davis, M.W., and Erlich, Robert, 1974, Late Paleozoic crustal composition and dynamics in the southeastern United States, in Briggs, Garrett, ed., Carboniferous of the southeastern United States: Geological Society of America Special Paper 148, p. 171-185.

Dennison, J.M., and Johnson, R.W., Jr., 1971, Tertiary intrusions and associated phenomena near the thirtyeighth parallel fracture zone in Virginia and West Virginia: Geological Society of America Bulletin, v. 82, p. 501-507.

Donaldson, A.C., 1974, Pennsylvanian sedimentation of central Appalachians, in Briggs, Garret, ed., Carboniferous of the southeastern United States: Geological Society of America Special Paper 148, p. 47-78.

Dyson, J.L., 1955, Relation of stratigraphy and structure to uranium occurrences near Mauch Chunk, Pennsylvania: Pennsylvania Geological Survey, Information Circular 5, p. 124-134.

Englund, K.J., Windolph, J.F., Jr., and Thomas, R.E., 1986, Origin of thick, low-sulphur coal in the Lower Pennsylvanian Pocahontas Formation, Virginia and West Virginia, in Lyons, P.C., and Rice, C.L., eds., Paleoenvironmental and tectonic controls in coal-forming basins of the United States: 
Geological Society of America Special Paper 210, p. 49-61.

Erickson, R.L., and Blade, L.V., 1963, Geochemistry and petrology of the alkalic igneous complex at Magnet Cove, Arkansas: U.S. Geological Survey Professional Paper 425, $95 \mathrm{p}$.

Fay, W.M., 1981, Cumberland and Pittsburgh $1^{\circ} \times 2^{\circ}$ NTMS areas, Maryland, Pennsylvania, Virginia, and West Virginia; data report (abbreviated); hydrogeochemical and stream sediment reconnaissance: Aiken, South Carolina, E.I. du Pont de Nemours, Savannah River Laboratory, Report No. GJBX-287-81, 18 p.

Fay, W.M., and Cook, J.R., 1982, Gold analyses by neutron activation from SRL NURE samples: Aiken, South Carolina, E.I. du Pont de Nemours, Savannah River Laboratory, Report No. GJBX-135-82, 33 p.

Fullagar, P.D., and Bottino, M.L., 1969, Tertiary felsite intrusions in the Valley and Ridge province, Virginia: Geological Society of America Bulletin, v. 80, p. 1853-1858.

Garnar, T.E., Jr., 1956, The igneous rocks of Pendleton County, West Virginia: West Virginia Geological and Economic Survey, Report of Special Investigations 12, $31 \mathrm{p}$.

Grimes, D.J., and Marranzino, A.P., 1968, Direct-current arc and alternating-current spark emission spectrographic field methods for the semiquantitative analysis of geologic materials: U.S. Geological Survey Circular $591,6 \mathrm{p}$.

Grogan, R.M., and Bradbury, J.C., 1968, Fluorite-zinc-lead deposits of the Illinois-Kentucky mining district, in Ore Deposits of the United States, 1933-1967 (GratonSales volume), v.1: New York, American Institute of Mining, Metallurgical, and Petroleum Engineers, p. 370-399.

Gwinn, V.E., 1964, Thin-skinned tectonics in the Plateau and northwestem Valley and Ridge Provinces of the central Appalachians: Geological Society of America Bulletin, v. 75, p. 863-900.

Harman, H.H., 1960, Modern factor analysis: Chicago, Ill., University of Chicago Press, $469 \mathrm{p}$.

Hinkle, M.E., Watts, K.C., Jr., and Griffitts, W.R., 1994a, Isopleth maps of iron, manganese, and selected elements in stream sediments of West Virginia: U.S. Geological Survey Miscellaneous Investigations Series Map I-2364-D, scale 1:1,000,000.

1994b, Isopleth map of $\mathrm{pH}$ and alkalinity in stream water and $\mathrm{Na}$ in stream sediments of West Virginia: U.S. Geological Survey Miscellaneous Investigations Series Map I-2364-E, scale 1:1,000,000

$1994 \mathrm{c}$, Isopleth map of uranium, thorium, cerium, and lanthanum in stream sediments of West Virginia: U.S. Geological Survey Miscellaneous Investigations Series Map I-2364-F, scale 1:1,000,000.
Honess, A.P., and Graeber, C. K., 1924, A new occurrence of an igneous dike in southwestern Pennsylvania: American Journal of Science, v. 7, no. 40, p. 313-315.

Honess, A.P., and Graeber, C.K., 1926, Petrography of the mica peridotite dike at Dixonville, Pennsylvania: American Journal of Science, v. 12, no. 72, p. 484-494.

King, E.R., and Zietz, I., 1978, The New York-Alabama lineament-geophysical evidence for a major crustal break in the basement beneath the Appalachian basin: Geology, v. 6, p. 312-318.

King, H.M., and Kirstein, D.S., 1987, Mineral resources of West Virginia: West Virginia Geologic and Economic Survey Map WV-24, scale 1:500,000.

King, E.R., Daniels, D.L., Hanna, W.F., and Snyder, S.L., 1994, Magnetic and gravity anomaly maps of West Virginia: U.S. Geological Survey Miscellaneous Investigations Series Map I-2364-H.

Motooka, J.M., and Grimes, D.J., 1976, Analytical precision of one sixth order semiquantitative spectrographic analysis: U.S. Geological Survey Circular 738, 25 p.

Motooka, J.M., 1988, An exploration geochemical technique for the determination of preconcentrated organometallic halides by ICP-AES: Applied Spectroscopy, v. 42, p. 1293-1296.

Olson, J.C., Shawe, D.R., Pray, L.C., and Sharp, W.N., 1954, Rare earth mineral deposits of the Mountain Pass District, San Bernardino County, California: U.S. Geological Survey Professional Paper 261, 75 p.

Pimentel, Nelly, Bikerman, Michael, and Flint, N.K., 1975, A new $\mathrm{K}$-Ar date on the Masontown dike, southwestern Pennsylvania: Pennsylvania Geology, v. 6 , no. 3, p. 5-7.

Price, Vaneat, and Jones, P.L., 1979, Training manual for water and sediment geochemical reconnaissance: Aiken, South Carolina, E.I. du Pont de Nemours, Savannah River Laboratory Report No. GJBX-420-81, 104 p.

Rader, E.K., Gathright, T.M., II, and Marr, J.D., Jr., 1986, Trimble Knob basalt diatreme and associated dikes, Highland County, Virginia, in Neathery, T.L., ed., Southeastern Section of the Geological Society of America Centennial Field Guide, p. 97-100.

Snyder, F.G., and Gerdemann, P.E., 1965, Explosive igneous activity along an Illinois-Missouri-Kansas axis: American Journal of Science, v. 263, no. 6, p. 465-493.

Thompson, C.E., Nakagawa, H.M., and Van Sickle, G.H., 1968, Rapid analysis for gold in geologic materials, in Geological Survey Research 1968: U.S. Geological Survey Professional Paper 600-B, p. B130-B132.

VanTrump, George, Jr., and Miesch, A.T., 1977, The U.S. Geological Survey RASS-STATPAC system for management and statistical reduction of geochemical data: Computers and Geosciences, v. 3, p. 475-488. 
Watts, K.C., Jr., Hinkle, M.E., and Griffitts, W.R., 1992, Evidence for a titaniferous diatreme or alkalic igneous rock in the subsurface, Harrison, Taylor, and Doddridge Counties, West Virginia: U.S. Geological Survey Open-File Report 92-366, 41 p.

1994, Isopleth map of titanium, aluminum, and associated elements in stream sediments of West Virginia: U.S. Geological Survey Miscellaneous Investigations Series Map I-2364-G, scale $1: 1,000,000$.

Woodward, H.P., 1968, Tectonic map of West Virginia in Cardwell, D.H, Erwin, R.B, and Woodward, H.P., comps., Geologic map of West Virginia, west sheet: West Virginia Geological and Economic Survey, scale $1: 2,000,000$.
Zartman, R.E., 1977, Geochronology of some alkalic rock provinces in eastern and central United States: Annual Review of Earth and Planetary Science, v. 5, p. 257-286.

Zubovic, Peter, Oman, C.L., Coleman, S.L., Bragg, L.J., Kerr, P.T., Kozey, K.M., Simon, F.O., Rowe, J.J., Medlin, J.H., and Walker, F.E., 1979, Chemical analysis of 617 coal samples from the eastern United States: U.S. Geological Survey Open-File Report 79-665, 458 p.

Zubovic, Peter, Oman, C.L., Bragg, L.J., Coleman, S.L., Rega, N.H., Lemaster, M.E., Rose, H.J., Golightly, D.W., and Puskas, John, 1980, Chemical analysis of 659 coal samples from the eastern United States: U.S. Geological Survey Open-File Report 80-2003, 517 p. 
Table 1. Summary of statewide NURE data

[Values in parts per million]

\begin{tabular}{|c|c|c|c|c|c|c|}
\hline \multirow[t]{2}{*}{ Element } & \multirow[t]{2}{*}{ Range } & \multirow[t]{2}{*}{ Mean } & \multicolumn{4}{|c|}{ Percentile distribution } \\
\hline & & & 50 & 90 & 95 & 99 \\
\hline $\mathrm{Al}$ & $2,000-96,200$ & 35,106 & 38,200 & 57,500 & 62,150 & 70,150 \\
\hline $\mathrm{Ce}$ & $220-881$ & 66 & 67 & 107 & 117 & 144 \\
\hline $\mathrm{Fe}$ & $5,000-265,000$ & 25,424 & 26,900 & 43,650 & 48,300 & 63,750 \\
\hline Hf & $2-1,329$ & 22 & 20 & 50 & 69 & 151 \\
\hline $\mathbf{L a}$ & $6-407$ & 33 & 35 & 51 & 56 & 74 \\
\hline Mn & $20-11,560$ & 453 & 500 & 980 & 1,180 & 1,985 \\
\hline $\mathrm{Na}$ & $100-54,600$ & 2,087 & 2,500 & 5,600 & 6,200 & 7,500 \\
\hline Sc & $0.2-21$ & 6.6 & 6.8 & 11 & 13 & 16 \\
\hline Sm & $1-75$ & 5.9 & 6.0 & 9 & 10 & 13 \\
\hline Th & $2-123$ & 10 & 10 & 16 & 18 & 23 \\
\hline $\mathbf{T i}$ & $300-98,400$ & 4,226 & 4,200 & 6,300 & 8,050 & 15,900 \\
\hline $\mathbf{U}$ & $0.2-66$ & 3.8 & 3.8 & 5.5 & 6.6 & 10 \\
\hline V & $10-220$ & 48 & 50 & 80 & 100 & 130 \\
\hline
\end{tabular}


Table 2. Varimax loadings showing element associations from R-mode factor analysis of merged USGS and NURE data, tract $A$

[Varimax loadings measure the degree of correlation of each element with each factor; only elements with varimax loadings higher than 0.30 are listed below; based on 352 samples; *, measured in stream water at the stream-sediment sample site; Alk is stream-water alkalinity, chiefly related to dissolved bicarbonate]

\begin{tabular}{|c|c|c|c|c|c|}
\hline \multirow[t]{2}{*}{ Element } & \multicolumn{5}{|c|}{ Factor } \\
\hline & 1 & 2 & 3 & 4 & 5 \\
\hline Al & 0.8189 & & & & \\
\hline $\mathbf{A u}$ & & 0.5398 & & & \\
\hline Alk* & & & & 0.6357 & \\
\hline B & & & 0.4228 & & \\
\hline $\mathrm{Ba}$ & 0.6031 & & & 0.4027 & \\
\hline $\mathrm{Be}$ & 0.7781 & & & & \\
\hline $\mathrm{Ca}$ & & & & 0.5161 & \\
\hline $\mathrm{Ce}$ & & 0.9257 & & & \\
\hline Co & 0.7881 & & & & \\
\hline $\mathrm{Cu}$ & 0.7126 & & & & 0.3889 \\
\hline $\mathrm{Fe}$ & 0.6333 & & & & \\
\hline $\mathrm{Ga}$ & 0.7126 & & & & \\
\hline $\mathrm{Hf}$ & & 0.9351 & & & \\
\hline $\mathrm{La}$ & & 0.9397 & & & \\
\hline $\mathbf{M g}$ & 0.6908 & & & 0.5871 & \\
\hline Mn & 0.7028 & & & & \\
\hline Mo & 0.4537 & & & & 0.5432 \\
\hline $\mathrm{Na}$ & 0.5656 & & & 0.7057 & \\
\hline $\mathrm{Nb}$ & & & 0.6117 & & \\
\hline $\mathrm{Ni}$ & 0.7851 & & & & \\
\hline $\mathrm{Pb}$ & 0.4414 & & & & 0.4388 \\
\hline $\mathrm{pH}^{*}$ & & & & 0.5631 & \\
\hline Sc & 0.7653 & & & & \\
\hline $\mathrm{Sn}$ & & & & & 0.4798 \\
\hline $\mathrm{Sr}$ & & 0.412 & & & 0.4923 \\
\hline Th & & 0.9356 & & & \\
\hline $\mathbf{T i}$ & & & 0.6736 & & \\
\hline $\mathbf{U}$ & & 0.9681 & & & \\
\hline V & 0.7731 & & & & \\
\hline $\mathbf{Y}$ & & 0.3367 & 0.3279 & & \\
\hline $\mathrm{Zn}$ & & & & & 0.5473 \\
\hline $\mathrm{Zr}$ & & 0.4817 & & & \\
\hline
\end{tabular}


Table 3. Selected product-moment correlation coefficients showing key element associations, anomaly A-1, tract $A$

[N, element reported from NURE analysis; all others emission spectrographic analysis; only correlation coefficients higher than 0.20 shown; based on 173 samples]

\begin{tabular}{|c|c|c|c|c|c|c|c|}
\hline \multicolumn{8}{|l|}{ Element } \\
\hline 1 & $\mathrm{Ti}$ & $\mathrm{Ce}(\mathbb{N})$ & $\mathrm{Mn}(\mathrm{N})$ & $\mathrm{Mn}$ & $\mathrm{Fe}(\mathrm{N})$ & $\mathrm{Fe}$ & $\mathrm{Cu}$ \\
\hline $\mathrm{Al}$ & & 0.52 & 0.35 & 0.33 & 0.33 & 0.38 & 0.6 \\
\hline $\mathrm{Ba}$ & & 0.26 & 0.32 & 0.47 & & 0.38 & 0.51 \\
\hline $\mathrm{Be}$ & & 0.24 & 0.24 & 0.37 & & 0.33 & 0.52 \\
\hline $\mathrm{Ce}(\mathrm{N})$ & 0.24 & & 0.23 & 0.24 & & & 0.23 \\
\hline Co & & & 0.46 & 0.61 & & 0.3 & 0.44 \\
\hline $\mathrm{Cu}$ & & 0.23 & 0.26 & 0.28 & 0.31 & 0.5 & \\
\hline $\mathrm{Fe}$ & & & & & 0.79 & & 0.5 \\
\hline $\mathrm{Fe}(\mathrm{N})$ & & & & & & 0.79 & 0.31 \\
\hline $\mathbf{G a}$ & & 0.38 & 0.25 & 0.33 & 0.26 & 0.39 & 0.65 \\
\hline $\mathrm{La}(\mathrm{N})$ & & 0.65 & & & & & 0.25 \\
\hline $\mathrm{Mg}$ & & 0.44 & 0.28 & 0.43 & & 0.31 & 0.47 \\
\hline $\mathrm{Mn}$ & 0.23 & 0.24 & 0.78 & & & & 0.28 \\
\hline $\operatorname{Mn}(\mathrm{N})$ & & 0.23 & & 0.78 & & & 0.26 \\
\hline Mo & & & & & & 0.23 & 0.26 \\
\hline $\mathrm{Na}$ & & 0.4 & 0.22 & 0.34 & 0.21 & 0.25 & 0.38 \\
\hline $\mathrm{Na}(\mathrm{N})$ & & 0.41 & & & & & \\
\hline $\mathrm{Ni}$ & & & 0.44 & 0.52 & 0.2 & 0.46 & 0.6 \\
\hline $\mathbf{P}$ & & & 0.23 & 0.31 & & & \\
\hline $\mathrm{Pb}$ & & 0.22 & & & & & 0.41 \\
\hline $\mathrm{Sr}$ & & 0.23 & 0.34 & 0.3 & & & 0.37 \\
\hline $\operatorname{Sc}(\mathrm{N})$ & & 0.4 & 0.29 & 0.43 & 0.34 & 0.37 & 0.61 \\
\hline Sc & & & & & 0.25 & 0.4 & 0.55 \\
\hline Th & 0.28 & 0.66 & & & & & \\
\hline $\mathrm{Ti}(\mathrm{N})$ & & 0.24 & 0.23 & & & & \\
\hline U & & 0.4 & & & & & \\
\hline $\mathrm{v}$ & & 0.3 & 0.22 & 0.4 & & 0.33 & 0.5 \\
\hline $\mathrm{V}(\mathbf{N})$ & & & 0.29 & & 0.23 & 0.26 & 0.43 \\
\hline
\end{tabular}


Table 4. Comparison of correlation coefficients for uranium-element pairs within West Virginia and within anomaly $A-2$, tract $A$

\begin{tabular}{lcc}
\hline Element & Statewide & Anomaly A-2 \\
\hline Ce & 0.51 & \\
Dy & 0.19 & 0.86 \\
Hf & 0.53 & 0.77 \\
La & 0.60 & 0.95 \\
Lu & 0.53 & 0.89 \\
Sm & 0.61 & 0.95 \\
Th & 0.52 & 0.90 \\
\hline
\end{tabular}

Table 5. Selected product-moment correlation coefficients showing key element associations, anomaly A-2, tract A

[N, element reported from NURE analysis; all others emission spectrographic analysis; only correlation coefficients higher than 0.30 shown; based on 174 samples]

\begin{tabular}{|c|c|c|c|c|c|c|c|}
\hline $\begin{array}{c}\text { Element } \\
1\end{array}$ & $\mathrm{Ti}(\mathbf{N})$ & $\mathrm{Ce}(\mathrm{N})$ & $\mathrm{Mn}(\mathrm{N})$ & Mn & $\mathrm{Fe}(\mathrm{N})$ & $\mathrm{Fe}$ & $\mathrm{Cu}$ \\
\hline$A l(N)$ & 0.66 & & 0.75 & 0.52 & 0.85 & 0.8 & 0.7 \\
\hline $\mathbf{B a}$ & & & 0.49 & 0.52 & 0.6 & 0.7 & 0.64 \\
\hline $\mathrm{Be}$ & 0.32 & & 0.64 & 0.61 & 0.66 & 0.73 & 0.67 \\
\hline Co & & & 0.64 & 0.67 & 0.6 & 0.71 & 0.63 \\
\hline $\mathrm{Cu}$ & 0.35 & & 0.63 & 0.62 & 0.75 & 0.79 & \\
\hline $\mathrm{Fe}$ & 0.36 & & 0.69 & 0.65 & 0.83 & 0.79 & \\
\hline $\mathrm{Fe}(\mathbf{N})$ & 0.55 & & 0.74 & 0.56 & & 0.83 & 0.75 \\
\hline Hf & & 0.89 & & & & & \\
\hline La & & 0.72 & & & & & \\
\hline $\operatorname{La}(\mathbf{N})$ & 0.45 & 0.97 & & & & & \\
\hline Ga & 0.35 & & 0.61 & 0.59 & 0.61 & 0.66 & 0.67 \\
\hline $\mathbf{M g}$ & 0.37 & & 0.65 & 0.65 & 0.76 & 0.86 & 0.79 \\
\hline Mn & & & 0.82 & & 0.56 & 0.69 & 0.62 \\
\hline $\operatorname{Mn}(\mathbf{N})$ & 0.52 & & & 0.82 & 0.74 & 0.65 & 0.63 \\
\hline $\mathrm{Na}$ & 0.42 & & 0.66 & 0.59 & 0.62 & 0.63 & 0.66 \\
\hline $\mathrm{Na}(\mathrm{N})$ & 0.53 & & & 0.51 & 0.67 & 0.66 & 0.66 \\
\hline $\mathbf{N i}$ & 0.32 & & 0.58 & 0.55 & 0.7 & 0.76 & 0.72 \\
\hline $\mathrm{Pb}$ & 0.32 & & 0.62 & 0.67 & 0.64 & 0.67 & 0.74 \\
\hline $\mathrm{Sc}(\mathbf{N})$ & 0.63 & 0.35 & 0.63 & 0.46 & 0.79 & 0.68 & 0.67 \\
\hline $\operatorname{Th}(\mathbf{N})$ & 0.41 & 0.95 & & & & & \\
\hline $\operatorname{Ti}(\mathbf{N})$ & 0.44 & 0.52 & & 0.55 & 0.36 & & \\
\hline $\mathrm{U}(\mathbf{N})$ & 0.88 & & & & & & \\
\hline V & 0.66 & 0.5 & 0.51 & 0.69 & 0.78 & 0.68 & \\
\hline$V(N)$ & 0.72 & 0.49 & 0.85 & 0.78 & 0.7 & & \\
\hline
\end{tabular}


Table 6. Varimax loadings showing element associations from $R$-mode factor analysis of merged USGS and NURE data tract from tract $B$

[Varimax loadings measure the amount of correlation of each element with each factor; only elements with varimax loadings higher than 0.30 are listed below; based on 185 samples]

\begin{tabular}{|c|c|c|c|c|c|}
\hline \multirow[t]{2}{*}{ Element } & \multicolumn{5}{|c|}{ Factor } \\
\hline & 1 & 2 & 3 & 4 & 5 \\
\hline Al & 0.9055 & & & & \\
\hline $\mathrm{Ag}$ & & 0.885 & & & \\
\hline As & 0.6342 & 0.6196 & & & \\
\hline B & 0.497 & 0.3632 & & & \\
\hline $\mathrm{Ba}$ & & 0.7631 & & & \\
\hline $\mathrm{Be}$ & 0.7449 & & & & \\
\hline $\mathrm{Ca}$ & & & & 0.7957 & \\
\hline $\mathrm{Cd}$ & & 0.9229 & & & \\
\hline $\mathrm{Ce}$ & 0.49 & & 0.5554 & & \\
\hline Co & 0.7449 & 0.326 & & & \\
\hline $\mathrm{Cr}$ & 0.7036 & & 0.3236 & & \\
\hline $\mathrm{Cu}$ & 0.3546 & 0.8963 & & & \\
\hline $\mathrm{Fe}$ & 0.8271 & & & & \\
\hline Ga & 0.902 & & & & \\
\hline Hf & & & 0.4911 & & 0.3238 \\
\hline $\mathbf{L a}$ & 0.7072 & 0.5756 & & & \\
\hline $\mathbf{M g}$ & 0.8436 & & & & \\
\hline $\mathbf{M n}$ & 0.7717 & & & & \\
\hline Mo & & 0.9242 & & & \\
\hline $\mathrm{Na}$ & 0.7803 & & & & \\
\hline $\mathrm{Nb}$ & & & & & 0.5529 \\
\hline $\mathrm{Ni}$ & 0.5303 & 0.6944 & & & \\
\hline $\mathrm{Pb}$ & 0.729 & 0.3825 & & & \\
\hline $\mathrm{Sb}$ & & 0.8382 & & & \\
\hline Sc & 0.839 & & & & \\
\hline $\mathrm{Sm}$ & 0.573 & & 0.5891 & & \\
\hline $\mathrm{Sr}$ & & & & 0.8586 & \\
\hline Th & 0.4646 & & 0.3544 & & \\
\hline $\mathbf{T i}$ & 0.5542 & & 0.5666 & & 0.4877 \\
\hline $\mathbf{U}$ & & & 0.6599 & & \\
\hline v & 0.8051 & 0.5207 & & & \\
\hline $\mathbf{Y}$ & & & & & 0.5914 \\
\hline $\mathrm{Zn}$ & 0.3787 & 0.8417 & & & \\
\hline $\mathrm{Zr}$ & & & & & 0.6057 \\
\hline
\end{tabular}


Table 7. Selected product-moment correlation coefficients showing key element associations with titanium and cerium, tract $B$

[N, element reported from NURE analysis; all others emission spectrographic analysis; only correlation coefficients higher than 0.30 shown; based on 185 samples]

\begin{tabular}{|c|c|c|}
\hline Element & $\operatorname{Ti}(\mathbf{N})$ & $\mathrm{Ce}(\mathrm{N})$ \\
\hline $\mathrm{Al}(\mathrm{N})$ & 0.71 & 0.56 \\
\hline B & 0.31 & \\
\hline $\mathrm{Be}$ & 0.33 & 0.34 \\
\hline Co & 0.43 & 0.42 \\
\hline $\mathrm{Ce}(\mathrm{N})$ & 0.54 & \\
\hline $\mathrm{Cr}$ & 0.59 & 0.44 \\
\hline $\mathbf{F e}$ & 0.57 & 0.48 \\
\hline $\mathrm{Fe}(\mathrm{N})$ & 0.59 & 0.56 \\
\hline $\mathrm{Ga}$ & 0.55 & 0.46 \\
\hline $\mathbf{L a}(\mathrm{N})$ & 0.66 & 0.69 \\
\hline Lu $(\mathrm{N})$ & 0.31 & 0.36 \\
\hline $\mathbf{M g}$ & 0.42 & 0.4 \\
\hline Mn & 0.48 & 0.46 \\
\hline $\operatorname{Mn}(\mathrm{N})$ & 0.54 & 0.49 \\
\hline $\mathrm{Na}$ & 0.44 & 0.34 \\
\hline $\mathrm{Na}(\mathrm{N})$ & 0.57 & 0.43 \\
\hline $\mathbf{N i}$ & 0.32 & 0.33 \\
\hline $\mathrm{Pb}$ & 0.37 & 0.39 \\
\hline Sc & 0.41 & 0.39 \\
\hline $\operatorname{Sc}(\mathrm{N})$ & 0.6 & 0.52 \\
\hline $\operatorname{Sm}(\mathbf{N})$ & 0.59 & 0.71 \\
\hline $\operatorname{Th}(\mathrm{N})$ & 0.41 & 0.38 \\
\hline $\mathrm{Ti}$ & 0.31 & \\
\hline $\operatorname{Ti}(\mathbf{N})$ & & 0.54 \\
\hline $\mathbf{U}(\mathbf{N})$ & 0.34 & \\
\hline $\mathbf{V}$ & 0.46 & 0.37 \\
\hline $\mathbf{V}(\mathbf{N})$ & & 0.5 \\
\hline
\end{tabular}

Table 8. Selected product-moment correlation coefficients showing key element associations, tract $L-1$

[*, characteristic of water at stream-sediment sample site; ALK, stream-water alkalinity related to dissolved bicarbonates; NURE data only; only correlation coefficients higher than 0.20 shown; based on 263 samples]

\begin{tabular}{cccc}
\hline Element & Ce & Mn & Fe \\
\hline $\mathrm{Al}$ & 0.23 & 0.56 & 0.73 \\
$\mathrm{Ce}$ & & 0.41 & \\
$\mathrm{Fe}$ & 0.41 & 0.51 & \\
$\mathrm{Hf}$ & 0.27 & & \\
$\mathrm{La}$ & 0.57 & & 0.29 \\
$\mathrm{Lu}$ & 0.51 & & \\
$\mathrm{Mn}$ & & & 0.51 \\
$\mathrm{Na}$ & 0.38 & 0.36 & 0.36 \\
$\mathrm{Sc}$ & 0.23 & & 0.45 \\
$\mathrm{Sm}$ & 0.62 & & 0.33 \\
$\mathrm{Th}$ & 0.53 & & 0.25 \\
$\mathrm{U}$ & 0.48 & & \\
$\mathrm{~V}$ & 0.38 & 0.42 & 0.5 \\
$\mathrm{Yb}$ & 0.39 & & 0.47 \\
$\mathrm{Alk}$ & & & \\
\hline
\end{tabular}


